\title{
Private Efforts for Affordable Mortgage Lending Before Fannie and Freddie
}

David A. Price and John Walter

A number of federal government initiatives in the United States have sought both to make home mortgages more broadly available and to increase the availability of features rendering those mortgages more affordable to borrowers, such as lower interest rates, long-term fixed rates, and lower down payments. Most notable among these initiatives have been the government-sponsored enterprises (GSEs) Fannie Mae, created in 1938 in response to the Great Depression, and Freddie Mac, established in $1970 .^{1}$

In the period prior to the advent of Fannie Mae, private activities played an important role in improving the affordability of U.S. mortgage markets, likely lowering interest rates as well as producing more favorable noninterest terms. Two examples of such activities are mortgage-backed securities (MBS) that arose in the late nineteenth century and the building and loan associations that first appeared in the early nineteenth century. Both of these financial arrangements were modeled after similar ones that appeared previously in Europe. In addition, large life insurance companies competed with other institutions for home mortgage lending business and grew to become important nationwide mortgage lenders between the 1880s and 1920s.

\footnotetext{
- The authors thank Jackson Evert, Arantxa Jarque, Bruno Sultanum, and John Weinberg for helpful comments. The views in this paper are those of the authors and not necessarily those of the Federal Reserve Bank of Richmond or of the Federal Reserve System.

${ }^{1}$ Such public efforts in the United States have been numerous, varied, and ongoing for a century. Edson (2011), p. 3.
} 
These historical activities of the private sector are of interest in two respects. First, they reflect a range of responses to the classic tension in mortgage lending: seeking the benefits of portfolio diversification and efficiencies of scale by pooling risks across regions, on one hand, versus seeking the benefits of local market knowledge and more effective oversight of agents by lending on a local scale, on the other. The GSEs have sought to manage this tension by combining national-level portfolios with measures such as imposing standardized underwriting requirements and demanding representations and warranties $^{2}$ from mortgage originators. In addition, the implicit public guarantee of the GSEs may have helped them paper over the tension to some extent until the crisis of 2007-08. Historical private-sector responses to the tension prior to the GSEs - and prior to the emergence of sophisticated information technology that has facilitated nationallevel mortgage lending and securitization - may be instructive. As will be seen, these private-sector institutions were not wholly successful in addressing the tensions either.

Second, the emergence and subsequent record of MBS issuers, building and loan associations, and life insurer mortgage operations of the nineteenth and early twentieth centuries could be suggestive of the types of institutions that would develop if GSEs were to become a less significant part of the mortgage landscape - through the operation of public policy or otherwise - and could shed light on the likely strengths and weaknesses of those emergent institutions.

\section{PRIVATE MORTGAGE-BACKED SECURITIES AND EQUIVALENTS}

MBS allow investors to achieve geographical diversification and open a broader pool of funds for mortgage borrowers. MBS in the United States have a long but checkered history extending back to the 1870s. The earliest MBS were loosely modeled after European mortgage banks, which issued the equivalent of today's covered bonds, backed by mortgages. ${ }^{3}$ These European institutions were often created by the government, in some cases were granted monopoly power by the government,

\footnotetext{
${ }^{2}$ Fannie Mae has explained, "Representations and warranties are a lender's assurance to the GSE that the GSE can rely on certain facts and circumstances concerning the lender and the mortgage loans it is selling. ... Violation of any representation and warranty is a breach of the Lender Contract, entitling Fannie Mae to pursue certain remedies, including a loan repurchase request." Fannie Mae, "Selling Guide Announcement SEL-2012-08," September 11, 2012, p. 1.

${ }^{3}$ In modern parlance, covered bonds are backed by a pool of assets (often mortgages) on the balance sheet of the bond issuer. The bonds are "covered" in that they are collateralized (i.e., covered) by the pool of assets.
} 
and operated under strict government rules. The European structures became important and long-lasting entities in the housing and building finance industries likely, in part, because of government aid that propped them up during episodes of financial distress. In the United States, issuers of MBS in the late nineteenth and early twentieth centuries suffered several episodes of wide-scale default but, in contrast to the earlier European experience, were not rescued by the public sector.

\section{Early European Mortgage Banks}

One of the earliest examples of MBS arose in Europe when, in 1770, Frederick the Great, king of Prussia, called for the creation of Landschaften mortgage-lending institutions. ${ }^{4}$ This first Landschaft was formed in 1770, soon after the end of the Seven Years War in 1763, and was located in the Prussian province of Silesia. Landschaften arose as a means of providing credit for agricultural production - for example, for the purchase of seed, horses, and cattle. The Seven Years War, and government credit policy actions following the war, had interrupted traditional credit channels. ${ }^{5}$ Landschaften were compulsory corporations including all land-owning nobles of a region. ${ }^{6}$ Landowners submitted their land as collateral, borrowed from the corporation, and the corporation sold bonds to investors to fund the loans. The Landschaften bonds were the liabilities of the corporation, but members were also jointly responsible for repayment of the bonds. ${ }^{7}$

A number of other Prussian provinces soon followed suit in setting up their own Landschaften. ${ }^{8}$ This arrangement shared two important features with later mortgage institutions in Europe: (1) government support for the formation and for the risk-limiting characteristics of the association (such as loan-to-value limits and restrictions on activities that might diminish the value of collateral) and (2) the creation of liabilities that were backed by a large portfolio of mortgages, producing a diversified source of income to support bond payments. Initially, between 1770 and 1830, Landschaften mortgage agreements provided only

\footnotetext{
${ }^{4}$ Tcherkinsky (1922), pp. 13, 14, 22; Snowden (1995b), p. 270.

${ }^{5}$ Wandschneider (2015), p. 794.

${ }^{6}$ Tcherkinsky (1922), p. 14. Wandschneider (2014), pp. 312-13, argues that the requirement that all landowners participate reduced the risk of an adverse selection problem limiting the attractiveness of Landschaft bonds. Wandschneider notes that "Adverse selection is an ex ante informational problem where under certain conditions only borrowers that are a poor credit risk will be attracted into a market. In response, lenders will not be willing to supply capital to this pool of "lemons."'

${ }^{7}$ Tcherkinsky (1922), p. 13.

${ }^{8}$ Tcherkinsky (1922), p. 15.
} 
for annual interest payments with no clearly specified repayment date. ${ }^{9}$ When repayment occurred it was either by repurchase of Landschaften bonds or with cash payments. But in the 1830s, the Landschaften introduced amortizing mortgage loans, whereby borrowers paid interest plus principal repayments that extinguished (amortized) their debt over time. ${ }^{10}$

The Landschaften were closely aligned with the government, likely encouraging the view that support would be forthcoming if they experienced financial trouble. Early Landschaften were begun using government-provided capital, and the president of the organization was chosen by the king. ${ }^{11}$ Some of the employees of Landschaften were chosen by local government assemblies, were sworn in and faced government discipline, and had the standing of state employees, including facing reduced taxes like other state employees. ${ }^{12}$ In at least one case the government borrowed from a regional Landschaft (East Prussia), against government-owned lands, to cover war-related expenses. ${ }^{13}$ The expectation of government support likely explains, in part, the low interest rates paid on Landschaften bonds and paid by the borrowers funded by Landschaften mortgages.

Indeed, Landschaften investors' belief that the government would protect their bond holdings seems to have been confirmed when between 1820 and 1830 the government came to the aid of troubled Landschaften in East Prussia and West Prussia. ${ }^{14}$ Therefore, it seems possible that without government aid, the Landschaft experience would have been similar to the later experience of U.S. mortgage companies and MBS issuers in the 1890s and during the Great Depression (discussed in the next section) that suffered pervasive failures but did not receive government aid.

These organizations survived widespread economic turmoil during the Napoleonic Wars (1803-15) and agricultural crisis during the 1820s and were operating until the end of World War II. ${ }^{15}$ Even fairly early in their history, they were significant lenders. For example, about onethird of land-owning estates in East Prussia had outstanding loans

\footnotetext{
${ }^{9}$ Wandschneider (2015), p. 317.

${ }^{10}$ Tcherkinsky (1922), pp. 33-34.

${ }^{11}$ Wandschneider (2015), pp. 794-95.

12 Tcherkinsky (1922), p. 26.

${ }^{13}$ Wandschneider (2015), p. 800.

14 Tcherkinsky (1922), pp. 43-44; Wandschneider (2015), pp. 800-01.

${ }^{15}$ Wandschneider (2015), p. 815; Wandschneider (2014), p. 307. Tcherkinsky (1922), pp. 22-23, notes that at the time of his writing, there were "in Germany ... 21 credit institutions of the Landschaft type." Tcherkinsky also provides a chronological table listing the location and year of formation (from 1770 through 1895) of rural Landschafts.
} 
from Landschaften as of $1823 .^{16}$ The amount of borrowing from Landschaften increased significantly in the latter half of the nineteenth century. ${ }^{17}$ Wandschneider (2015) argues that Landschaften were responsible for lowering the cost of credit for agricultural estates and increasing the value of the estates that could borrow from Landschaften. Rates on Landschaften bonds were similar to rates on government bonds and they were popular investments in Prussia and internationally, thus providing an extensive source of funding for Prussian mortgage borrowers.

\section{U.S. Mortgage Companies and Private MBS}

MBS-issuing institutions in the United States arose in the 1870s and filled a niche for a nationally diversified source of funds for home and farm mortgages. Specialized mortgage lenders, such as United States Mortgage Company, provided mortgages and issued MBS, but mortgage insurance companies also established trusts that purchased mortgages and issued MBS, employing the model that was later adopted by Fannie Mae and Freddie Mac.

While in the eighteenth century Landschaften provided an internationally derived source of funds for Prussian borrowers, even in the late 1800s lending by institutions accounted for far less than half of U.S. mortgage lending, so the United States seemed ripe for growth of institutions that could provide these diversification and funding-sourcewidening benefits. (In some parts of the country, lending institutions did play an important role - especially in New England and the Pacific states.) ${ }^{18}$ An apparent difference between the U.S. and the European experience is that in Europe the development of regional or nationwide mortgage markets had been encouraged, regulated, and subsidized, while in the United States such markets had, to a degree, been discouraged by legislation that limited the range of banks and some other potential lenders.

Because some commercial banks, savings banks, mutual savings banks, and life insurance companies were, in many cases, prohibited from mortgage lending on an interstate basis, other entities not subject to these prohibitions filled the gap to provide a means of diversified (nationwide) mortgage lending along with local credit analysis. These entities were mortgage companies or mortgage trusts and began being formed in the early 1870 s. ${ }^{19}$

\footnotetext{
${ }^{16}$ Wandschneider (2015), p. 805.

${ }^{17}$ Wandschneider (2015), p. 318.

${ }^{18}$ Snowden (1995a), p. 220.

19 Brewer (1976), pp. 358-61.
} 
National banks (those banks chartered by the federal government rather than state government) were prohibited from investing in mortgages by the National Bank Act of 1864. This prohibition remained in place until 1913. ${ }^{20}$ New York-headquartered life insurance companies, which held 50 percent of all U.S. life insurance assets, could invest only in mortgages on properties within that state or within fifty miles of New York City until at least the late 1870s. ${ }^{21}$ Mutual savings banks, significant members of the banking community in the northeastern portion of the United States, were typically limited to making mortgages on properties in their home states in the late nineteenth century. ${ }^{22}$ Given limited interstate communication and transportation technology in the nineteenth century, such restrictions were likely viewed by supervisors as reasonable limitations for safety and soundness purposes or perhaps as a way to ensure that deposits gathered locally were also invested locally, but the restrictions probably significantly limited competition for mortgage loans outside of the Northeast.

One of the mortgage entities that arose in this environment that restricted bank and insurance company mortgage lending was United States Mortgage Company, which is described in detail by Brewer (1976) ${ }^{23}$ The company was chartered by legislation passed by the state of New York in 1871. The company lent to mortgage borrowers-both residential and farm - in the United States and issued bonds equal to its mortgage holdings. ${ }^{24}$ It offered borrowers the option of paying off their loans in installments (i.e., an amortizing loan) or paying in full at maturity. ${ }^{25}$ Bonds issued by United States Mortgage Company had maturities of five to fifty years. ${ }^{26}$ Given that the company's securities - or bond issues - were backed by mortgage loans, these issues amounted to nineteenth-century MBS. These MBS were the liabilities of the United States Mortgage Company, much as today's Fannie Mae- and Freddie

\footnotetext{
${ }^{20}$ Davis (1965), p. 358 .

${ }^{21}$ Davis (1965), p. 383; Brewer (1976), p. 358 and footnote 11. Brewer (1976), p. 358 , notes that mortgages accounted for 54 percent of life insurance company assets in 1875 .

${ }^{22}$ Brewer (1976), pp. 358-59.

${ }^{23}$ See Brewer (1976), pp. 362-72. United States Mortgage Company was ultimately absorbed by Chemical Bank, which merged with Chase Manhattan Bank in 1996, keeping the Chase name. Chase and J.P. Morgan merged in 2000 to form today's JPMorgan Chase. See Brewer (1976), p. 363, footnote 25; Hansell (1995); and JPMorgan (2017).

${ }^{24}$ Brewer (1976), p. 363.

${ }^{25}$ Brewer (1976), p. 363.

${ }^{26}$ Brewer (1976), pp. 364-65.
} 
Mac-issued MBS are the liabilities of Fannie Mae and Freddie Mac. ${ }^{27}$ United States Mortgage Company MBS were held by investors in the United States and in Europe.

Mortgage bonds were attractive investments at the time because of the limited number of competitor securities. For example, U.S. Treasury securities were paying an unusually low rate of interest at the time because banks were required by law to hold them to back their currency issues, thus creating heavy demand for Treasuries and driving down the interest rates they paid. The other main competitor bonds were railroad bonds, and those were disfavored by investors in the mid1870 s due to widespread bankruptcies by railroad companies. ${ }^{28}$ United States Mortgage Company created earnings by lending at an interest rate that exceeded the interest rate it paid on its bonds. ${ }^{29}$

Lending by United States Mortgage focused heavily on western mortgages with lending boards created in Chicago and St. Louis. Bonds were sold in Europe, through a Paris office, and were also listed on the New York Stock Exchange beginning in 1874. The company established local lending "boards" to handle mortgage loan origination, pricing, and credit quality. ${ }^{30}$

But United States Mortgage was not alone. According to Snowden (1995b), seventy-four western mortgage companies were selling mortgage backed securities (mostly based on farm mortgages) in Massachusetts and New York between 1890 and 1897, and their issues amounted to $\$ 800$ million at a time when total mortgage debt outstanding was about $\$ 6$ billion. ${ }^{31}$ The issuers of these bonds also guaranteed them against default risk. Still, by 1897 most of these entities had failed (many by defaulting on their securities issues) due to a decline in western land values.

MBS, created by insurance companies, and with structures almost identical to those used by Fannie Mae and Freddie Mac today (whereby securities representing a proportional cash flow of underlying mortgages are sold to investors, with the seller providing default insurance

\footnotetext{
27 Before 2010, MBS issued by Fannie Mae and Freddie Mac were guaranteed (in terms of principal and interest payments) by Fannie Mae and Freddie Mac but not shown on their balance sheets as their liabilities. Following an accounting rule change that took effect in 2010, these MBS are now shown as Fannie Mae and Freddie Mac liabilities. One difference between Fannie Mae and Freddie Mac and United States Mortgage Company is that the latter actually made the mortgage loans itself, while Fannie Mae and Freddie Mac buy mortgages from outside lenders.

28 Brewer (1976), pp. 359-60.

${ }^{29}$ Brewer (1976), p. 360.

30 Brewer (1976), p. 364.

31 See Snowden (1995b), p. 278; Snowden (1995a), p. 220.
} 
for the securities), arose and grew large in New York in the 1920s. ${ }^{32}$ These MBS structures developed over a period of forty years starting first in the late 1880s when several New York-headquartered companies formed for the purpose of guaranteeing mortgage payments due to mortgage investors and providing title insurance. This mortgageguarantee business was small until after World War I, when a boom in construction caused a rapid increase. In 1921, New York firms guaranteed $\$ 500$ million worth of loans and by $1932, \$ 2.8$ billion. ${ }^{33}$ The latter figure compares to $\$ 24.9$ billion in outstanding residential mortgages in $1932 .{ }^{34}$

At first, the mortgage payment and title insurance companies simply provided default insurance on mortgage payments. But in 1906 companies began selling participation certificates in guaranteed (in terms of principal and interest payments) mortgage pools - the same MBS structure employed by Fannie Mae and Freddie Mac today. By 1933, the outstanding amount of mortgage-participation certificates was $\$ 810$ million, which had been sold to 213,000 separate investors. ${ }^{35}$

During the Great Depression, rapidly declining house prices and homeowner incomes meant that most of the guarantee companies failed and many participation certificate investors suffered proportionally large losses on their investments. Ultimately, following the Depression-era failures of these structures, many as a result of weak underwriting standards of the lenders, federal and state laws were passed that prohibited mortgage insurance, a fundamental feature of the structures, for the next two decades. ${ }^{36}$

\section{BUILDING AND LOAN ASSOCIATIONS}

Another private effort to lower the cost of housing prior to the GSEs was a form of thrift institution known as building and loan associations. They were based on notions of mutual self-help, that is, selfreliance combined with mutual aid: individuals held shares in the institutions and, in return, had borrowing privileges as well as the right to dividends. Broadly speaking, while operating plans varied, members committed to make regular payments into the association and took turns taking out mortgages with which to buy homes; the determination of the next borrower was often decided by an auction among the

\footnotetext{
${ }^{32}$ Snowden (1995b), p. 283-88.

${ }^{33}$ Alger and Cook (1934), pp. 7-9.

${ }^{34}$ Grebler, Blank, and Winnick (1956), p. 443.

${ }^{35}$ Alger (1934), p. 3.

${ }^{36}$ Snowden (1995b), pp. 283, 285-86.
} 
membership. From their advent in the 1830s until their demise during the Great Depression, building and loan associations were generally small and local. At the peak of their numbers in 1927, some 12,804 of the associations were in operation with 11.3 million members - at a time when the entire U.S. population was only 119 million - and $\$ 7.2$ billion in assets. ${ }^{37}$ In addition, a rival group of "national" building and loans was a significant force from the 1880s until the late 1890s.

Because the primary purpose of a building and loan was to make home mortgages accessible to its members, they developed loan products with payment terms that were more attractive to typical homebuyers. Where mortgages from commercial banks during the 1920s had an average length of three years and were nonamortized, those from buildings and loans averaged eleven years and 95 percent were self-amortizing. ${ }^{38}$

\section{Early Development and Diffusion}

American building and loan associations had their roots in British building societies, which appear to have originated in Birmingham, England, in the 1770s or 1780s. ${ }^{39}$ At least a dozen of the societies were founded in Birmingham in the last quarter of that century. ${ }^{40}$ These increased to sixty-nine societies by 1825 and then proliferated rapidly to 2,050 by $1851 .{ }^{41}$ In general, members bought shares and paid for them over time and rotated receiving home loans - until all the members had taken a turn, at which point a society terminated. ${ }^{42}$

The British working class at the time already had a longtime tradition of "friendly" societies, cooperatives of mutual self-help to which members would make regular payments and from which they could receive a loan in the event of certain hardships, such as fire, job loss, or sickness. ${ }^{43}$ Conceptually, it was perhaps a short distance from the institution of the friendly society to that of the building society. Britain in the nineteenth century may also have been fertile soil for building

\footnotetext{
${ }^{37}$ Bodfish (1931), p. 136. At that time, the total residential mortgage debt held by all lenders was approximately $\$ 24.4$ billion. Grebler, Blank, and Winnick (1956), p. 466. While 1927 was the peak year for the number of associations, the number of members and total assets continued to increase briefly.

${ }^{38}$ White (2014), p. 136. Although longer loan terms likely made the loans more costly in the aggregate given the greater interest expense, they were desirable and more affordable in the sense that they resulted in lower monthly payments.

39 Mason (2004), p. 14; Bodfish (1931), p. 11; Price (1958), p. 20.

40 Price (1958), p. 21.

${ }^{41}$ Mason (2004), p. 15.

42 Mason (2004), p. 14.

${ }^{43}$ Mason (2004), p. 13.
} 
societies because ideas of mutual self-help were in the air more generally in other settings. Mutual-improvement societies, for example, were groups of working-class men who combined money to buy reading material that they shared for discussion at meetings. ${ }^{44}$

The conditions that apparently drove the application of these ideas to homebuying were created by the Industrial Revolution. The rise of factory work meant, for many, regular wage incomes. Higher-skilled workers with relatively greater incomes might wish to purchase a home to avoid tenement-like conditions and to gain the accumulation of equity possible through mortgaging rather than leasing. (In addition, homeownership brought with it the right to vote for one's representative in Parliament.) But those workers were stymied by the conventional mortgage offerings of the time with their high down payment requirements and short loan terms. ${ }^{45}$ The British building society enabled some to overcome these obstacles.

The building society model appears to have been transmitted from Britain to the United States by British immigrants. The first building and loan association, Oxford Provident Building Association, was founded in Frankford, Pennsylvania, (now part of Philadelphia) in 1831 by two factory owners who were natives of England. ${ }^{46}$ The model spread from there to the northeast and mid-Atlantic, with associations established in Connecticut, Maryland, New Jersey, and New York by 1850, along with additional associations in Pennsylvania. ${ }^{47}$ (In addition, several associations were established in Charleston, South Carolina, during this period, at least one of them founded by an English immigrant. ${ }^{48}$ ) Associations were established in the majority of other states during the 1860s and 1870s. Illinois, California, and Texas leapfrogged other states outside the East Coast, with associations established in 1851, 1865, and 1866, respectively, a pattern that may have been the result of westward migration of individuals who were familiar with the model. ${ }^{49}$

As in Britain, the growth of building and loan associations in the United States was likely aided by the factory system and the swelling of a wage-earning class - combined with a dearth of affordable financing sources for homebuyers. ${ }^{50}$ As noted earlier, under the National Bank Act of 1864, national banks were not permitted to make loans

\footnotetext{
${ }^{44}$ Griffin (2013), pp. 174, 177.

${ }^{45}$ Mason (2004), pp. 13-14; Price (1958), pp. 130-31; Foulke (1941), pp. 146-47.

${ }^{46}$ Haveman and Rao (1997), p. 1608; Foulke (1941), p. 147.

${ }^{47}$ Foulke (1941), p. 182; Bodfish (1931), pp. 76-83.

${ }^{48}$ Bodfish (1931), pp. 562-64.

${ }^{49}$ Mason (2004), p. 29; Bodfish (1931), pp. 81, 84.

${ }^{50}$ Foulke (1941), p. 146.
} 
secured by real estate. ${ }^{51}$ Mortgages from state commercial banks required large down payments, up to 60 percent of the home's value, and the loans were short-term (typically five years or less) and nonamortized. Mutual savings banks - which, notwithstanding the name, were not cooperatively owned - offered longer loan terms than commercial banks, but their mortgages still involved high down payments. Insurance companies - another source of mortgage finance in the nineteenth century, as discussed more fully below - also required high down payments. ${ }^{52}$

In the early decades of American building and loan associations, during the first half of the nineteenth century, they closely followed the form of operation of the British building societies. This model came to be known as the "terminating plan," so named because an association's existence was required to be wound up at a predefined point-when all of its loans had been repaid, or more precisely, when the shares of stock that members purchased over time in connection with membership had matured. ${ }^{53}$

An illustration of how the terminating plan worked, taken from that of the Oxford Provident association, is the following. ${ }^{54}$ The building and loan would be formed by a group of individuals (members), each of whom paid a membership fee of $\$ 5$ at the time of formation. Each member also subscribed to a number of shares of stock-between one and five shares - with a predetermined maturity value or par value of, say, $\$ 500$. Then each member was required to pay in $\$ 3$ per month per share until the amount paid in per share equaled the shares' maturity value. In general, no other members were allowed to join unless they paid, up front, an amount equal to that already paid in by the founding members. Once members' payments reached the maturity value of the shares, the association was terminated and members were repaid.

While the association was operating, members could pledge their stock and thereby take out home mortgage loans equal to as much as the matured value of all their shares of stock (though at the time of the loan, the member might have paid in much less than this amount). For example, if a member had subscribed to five shares, each with a maturity value of $\$ 500$, the member could borrow as much as $\$ 2,500$. (The borrower pledged his or her stock when taking out a mortgage, then continued paying for the stock on an installment plan until the

\footnotetext{
${ }^{51}$ Behrens (1952), p. 15.

${ }^{52}$ Mason (2004), pp. 16-17.

${ }^{53}$ Bodfish (1931), pp. 85-86.

${ }^{54}$ Byers (1927), p. 20; Bodfish (1931), pp. 35-36.
} 
stock was paid for, which had the effect of cancelling the loan. ${ }^{55}$ ) In the rotation of home loans, members who wished to receive the next loan bid against one another; the bidding determined the premium that the winner would pay to secure that place in the rotation. Most commonly, the amount of the premium would be deducted from the loan when it was disbursed. ${ }^{56}$

The relative simplicity of the terminating plan made it an attractive framework for the associations during the first decades of the movement. A difficulty of the terminating plan, however, is that it was burdensome for members to join once an association was underway: as noted, all shares were issued at the same time, so members who joined later were required to pay a lump sum on entry to cover the payments they had missed. (In modern terms, a terminating plan was "closed end" in the sense that it generally issued shares only at its inception.) Moreover, in the waning period of the association's life, an association with idle money to lend and no borrower to take it might require a member (chosen by lot) to accept a loan whether he wanted it or not. Finally, the automatic termination of an association was perceived by some as wasteful given the efforts involved in organizing it and its potential usefulness if it were a continuing concern. ${ }^{57}$

The 1850s saw the emergence of a variation on the terminating plan that partially addressed these shortcomings. An association organized under the "serial plan" issued multiple series of shares over the course of its existence. In effect, a serial-plan association was like a collection of terminating-plan groups, each with its own onset and termination dates, under one organizational umbrella. New series were commonly offered on a quarterly or semiannual schedule. Thus, someone who had not been a member at the association's birth could join when the association later issued a new series of shares without the obstacle of making a back payment. Because the association was periodically adding member-borrowers to its rolls, there was no need to require someone to take an unwanted loan. Finally, the association as a whole had no defined termination date. ${ }^{58}$

A third form of organization, the permanent plan, arose in the 1870s. It did away with the concept of series of shares and instead issued shares to each member that were independent of the shares of other members; consequently, members could join and leave at the

\footnotetext{
${ }^{55}$ Dexter (1889), pp. 316-17.

${ }^{56}$ Wrigley (1869), pp. 29, 71.

${ }^{57}$ Bodfish (1931), p. 86; Mason (2004), pp. 18-19.

${ }^{58}$ Bodfish (1931), p. 87; Mason (2004), p. 19; Mason (2012), p. 382; Snowden (1997), p. 231; Foulke (1941), pp. 182-83
} 
times of their own choosing. ${ }^{59}$ As noted by Haveman and Rao (1997), the structural evolution from the terminating plan to serial and then permanent plans enabled building and loans to serve a sometimes transient homebuying population with less burdensome, more flexible arrangements. ${ }^{60}$

Still another plan, specific to the city of Philadelphia, had a separate track of development. There are conflicting accounts of when it originated, but a majority of sources point to the first half of the nineteenth century. ${ }^{61}$ Under the Philadelphia plan, the homebuyer making a 20 percent down payment financed the other 80 percent by taking out a first mortgage for 50 percent of the purchase price from a bank, insurance company, or other lender, together with a second mortgage for 30 percent of the purchase price from a building and loan association. The result of this arrangement was low monthly payments: on the first mortgage - which typically had a three- to five-year term but could readily be renewed - the purchaser made interest-only payments. On the second mortgage, the purchaser made full self-amortizing payments, but the loan term was longer, typically eleven years. ${ }^{62}$

The Philadelphia plan was the predominant method of home finance within that city. It saw little adoption elsewhere, however, perhaps in part because most states did not allow a building and loan association to hold a second mortgage on a property for which it did not also hold the first mortgage; in those states, evidently, the secondmortgage business was considered too risky for building and loans. ${ }^{63}$ In any event, the Philadelphia plan represented a distinctive and successful model of affordable lending, apparently contributing to the city's high rate of homeownership. ${ }^{64}$

With the further increase in U.S. urbanization in the 1880s, building and loan associations experienced a major wave of growth; thousands of local associations were founded. ${ }^{65}$ Associations spread into every state during this decade (except Oklahoma, which saw its first building and loan in 1890). ${ }^{66}$ By 1893, according to a survey taken by the U.S. commissioner of labor, there were 5,598 local associations

\footnotetext{
${ }^{59}$ Bodfish (1931), pp. 93-94; Foulke (1941), p. 183.

${ }^{60}$ Haveman and Rao (1997), p. 1638.

${ }^{61}$ Loucks (1929), pp. 7-8.

${ }^{62}$ Loucks (1929), pp. 1, 6.

${ }^{63}$ Loucks (1929), pp. 1-2, 6.

${ }^{64}$ Among the eleven U.S. cities with a population above 500,000, Philadelphia in 1920 ranked second in its percentage of owner-occupied homes (39.5 percent). Loucks

${ }^{65}$ Snowden (1997), p. 228.

${ }^{66}$ Bodfish (1931), p. 81.
} (1929), p. 39. 
with a total of $1,349,437$ members and $\$ 473.1$ million in assets. ${ }^{67}$ The same survey indicated that the associations' memberships drew heavily from the working class; among the associations that reported their members' occupations, over 59 percent of members were "laborers and factory workers," "housewives and housekeepers," or "artisans and mechanics." 68

While the serial, permanent, and terminating plans continued to dominate, a new form of organization emerged during this period. The Dayton plan, first used in Dayton, Ohio, in the early or mid-1880s, permitted some members to participate only as savers without borrowing, somewhat reducing the centrality of mutual self-help in those institutions. ${ }^{69}$ In addition, it allowed borrowers to determine their own payment amounts, with higher payments reducing their total interest, a feature that partially anticipated the structure of a typical modern mortgage allowing early prepayment without penalty.

\section{The National Associations: A Cul-de-Sac}

Beginning in the mid-1880s, a class of national building and loan associations emerged. Unlike the local associations, the national associations operated across city and state lines by opening branches. The term "national" referred to the nonlocal scale of the associations rather than any federal-level regulation or charter. (The term was somewhat of a misnomer since the associations could not operate on a truly nationwide basis; some large states adopted laws effectively barring "foreign"that is, out-of-state - associations from doing business within their borders by requiring them to put up prohibitively high bonds with the state. $^{70}$ ) From their starting point of two institutions in Minneapolis, Minnesota, the national associations had grown by 1893 to some 240 national associations, with at least one established in every state. ${ }^{71}$

According to economic theory, national associations could have brought about more efficient allocation of capital compared to local associations, all other things equal: their larger geographic scope meant they could receive deposits (sell shares) in markets where loanable funds were abundant and make home loans in markets with high

\footnotetext{
${ }^{67}$ Bodfish (1931), pp. 134-36.

${ }^{68}$ Mason (2004), p. 29.

${ }^{69}$ Snowden (1997), p. 233; Mason (2004), p. 20; Haveman and Rao (1997), pp. 1617-19. Bodfish (1931) puts the introduction of the Dayton plan by the Mutual Home and Savings Association of Dayton, Ohio, at 1880, while Mason (2004) puts it at the mid-1880s.

${ }^{70}$ Bodfish (1931), p. 113; Haveman and Rao (1997), p. 1639.

${ }^{71}$ Bodfish (1931), p. 104.
} 
demand. The national associations cited this advantage in one of their publications in 1889, stating that they were "selling stock in vicinities where money is plenty and loaning it where money is scarce, which locals cannot depend upon doing." In addition, the national associations contended, they were able to "supply loans of larger dimensions than the local societies could fill" and "supply money to towns and villages which are not large enough to support a local association." 72 Their larger scope also brought benefits of greater diversification in their loan portfolios as well as efficiencies of scale.

The financial structure of the national associations had roots in the permanent-plan form of the local associations. But there were significant differences between the two. Where all of a member's payments into a local building and loan went into paying down his or her shares, payments into a national association went in part to an "expense fund" that served to boost the organizers' profits. The portion allocated to the expense fund varied from one association to another; a range of 5 percent to 7 percent appears to have been common. ${ }^{73}$ Local associations did, of course, spend a portion of their funds on operating expenses, but the amounts involved were much lower at 1 percent to 2 percent of revenues. ${ }^{74}$ Moreover, if a member of a national association failed to keep up his payments, he would forfeit the payments he had already made even if he had not yet taken a loan. ${ }^{75}$ (Additionally, as with any mortgage, those who had taken a loan were subject to foreclosure of their houses.) Countervailing these disadvantages, from the point of view of prospective members, were the high rates of return that the national associations advertised: the dividend yields they promised were several times those available from banks, local associations, or government bonds. ${ }^{76}$

The local associations responded to the new entrants in part by forming statewide trade groups that fought the nationals through public education - that is, vituperative criticism - and restrictive legislation. (In some states, trade groups for local building and loan associations were already in place before the emergence of the nationals. ${ }^{77}$ ) These organizing efforts within the industry culminated in 1893 in the formation of a nationwide body of the state trade groups, the U.S. League of Local Building and Loan Associations; its first

\footnotetext{
${ }^{72}$ Bodfish (1931), p. 106.

${ }^{73}$ Bodfish (1931), pp. 109, 111.

${ }^{74}$ Mason (2004), p. 33.

${ }^{75}$ Bodfish (1931), p. 101; Haveman and Rao (1997), p. 1639.

${ }^{76}$ Mason (2004), p. 33; Bodfish (1931), pp. 102-03.

${ }^{77}$ Mason (2004), p. 38.
} 
convention took place that year in Chicago in conjunction with the World's Columbian Exposition. ${ }^{78}$ In addition to opposing the national associations, the state groups and their national body were concerned with promoting homeownership and the local associations. ${ }^{79}$

In their criticisms of the new entrants, the groups representing the local associations held that the nationals were cooperatives in theory but proprietary for-profits in fact. A U.S. League publication argued, "The only object in organizing or carrying on the [national] association is to create and gobble up this expense fund. Their name should be changed." 80 Seymour Dexter, founder and first president of the U.S. League, told the league's second convention in 1894, "Whenever so fine a field of operations presents itself to the scheming and dishonest as the present system of the National Building and Loan Association, we may rest assured that the scheming and dishonest will enter it and pluck their victims until restrained by proper legal restrictions." 81

Whatever the share of national associations with "scheming and dishonest" organizers, a weakness of their business model was the difficulty of monitoring - of assessing properties and real estate market conditions in branch areas. This difficulty reflected the informational disadvantage of a centralized lending operation; the information technology that would eventually help lenders overcome the disadvantages of distance in home mortgage lending was, of course, not yet in place. Consequently, in contrast with the local associations and their locally based operations, national associations ran a higher risk of lending on the basis of inflated appraisals or lending to poor-quality borrowers. ${ }^{82}$

The downfall of the national associations was put in motion by a major real estate downturn associated with the Depression of 1893. In the first few years of the downturn, the assets of the nationals actually grew as they were perceived as a low-risk investment, but they would come to be hard hit. ${ }^{83}$ While mortgage lenders in general suffered, national building and loans were particularly vulnerable on account of the lower average quality of their loans. In addition, as economic conditions reduced the number of new members, the national associations lost a source of new expense-fund contributions and other fees, which some institutions relied on to meet their obligations. ${ }^{84}$ The knockout blow for the national associations was the failure in 1897 of the largest of

\footnotetext{
${ }^{78}$ Bodfish (1931), pp. $140-43$.

${ }^{79}$ Mason (2004), p. 38.

${ }^{80}$ Bodfish (1931), p. 108.

${ }^{81}$ Bodfish (1931), p. 107.

${ }^{82}$ Mason (2004), p. 34.

${ }^{83}$ Mason (2012), p. 386-87.

${ }^{84}$ Haveman and Rao (1997), pp. 1639-40; Mason (2004), p. 36.
} 
them, the Southern Building and Loan Association of Knoxville, Tennessee, which gravely damaged confidence in the remaining nationals; virtually all of those institutions ceased operation within a few years. ${ }^{85}$

\section{Final Wave of Growth in the 1920s and Demise}

During and after the collapse of the national building and loan associations, some in the local building and loan movement expressed concern that the record of the nationals would leave a long-term stigma on the local associations. An article in the official newsletter of the Building Association League of Illinois and Missouri, for example, noted in 1896 that in many "smaller cities and towns" hundreds of savers had trusted their money to a national association only to lose it all. "It will be years," the newsletter held, "before it will be possible to establish a genuine building and loan association in such a community, after the name of building association has been besmirched and prostituted, and brought into grave disrepute through the actions of the schemers who have run these bogus concerns." 86

Although the membership and assets of local building and loans did remain essentially flat during the first few years of the 1900s, perhaps as a result of the stigma left by the failed national associations, they resumed their growth afterward: from about 1.5 million members and $\$ 571$ million in assets in 1900 to about 2.2 million members and $\$ 932$ million in assets in 1910. Even more rapid growth was still to come: by 1920 , membership had more than doubled to nearly 5 million and assets had grown more than $21 / 2$-fold to $\$ 2.5$ billion. (The number of associations also rose, but less dramatically, reflecting an increase in the average institution size: from 5,356 in 1900 to 5,869 in 1910 and 8,633 in 1920.) In 1930, despite the financial crisis the preceding year, membership was up to 12.3 million and assets totaled $\$ 8.8$ billion. ${ }^{87}$

Several developments aided the growth of the local associations and of their model of affordable mortgage lending during this period. One is that the locals became more promotion-minded and more sophisticated about promotion. While hard data on their promotional efforts are scarce, it appears that the locals during this time increasingly supplemented their primary means of acquiring new membersword of mouth - with the use of newspaper advertisements and window

\footnotetext{
${ }^{85}$ Mason (2004), p. 37; Bodfish (1931), pp. 114-15.

86 "Downfall of the 'Nationals."' (1896).

${ }^{87}$ Bodfish (1931), p. 136 (table 1).
} 
displays. ${ }^{88}$ This shift appears to have been partly the result of encouragement and guidance from the U.S. League ${ }^{89}$ but is also consistent with the increasing scale of the local associations, which could better support such efforts.

Another development that boosted local associations during this time was the real estate boom in California and other western states, together with the embrace of building and loan associations there as a form of affordable housing finance. The assets of building and loans in the West grew from 1920 to 1930 at an average annual rate of 47.1 percent, compared with 25.1 percent for the nation as a whole. ${ }^{90}$

Additionally, the 1920s saw a trend of developers and builders establishing, in effect, captive associations that they dominated to support the sale of their houses. While developers, builders, and brokers had long been involved in local building and loan associations, there is evidence that they went further during this period in coopting the building and loan model, possibly boosting the numbers of building and loans. ${ }^{91}$

Recessions were frequent during this period, even before the Great Depression - eight recessions occurred from 1900 to 1928, an average of one every three and a half years ${ }^{92}$ — but these did not appear to interfere with the growth of building and loans. In general, building and loans tended to be more stable than banks during periods of market stress, such as the panic of 1907 , because their savers were member-owners rather than creditors. While bank depositors could, by definition, demand the immediate return of demand deposits, not all building and loan plans allowed for withdrawal before a prescribed maturity date, and under those plans that did, the association had a significant period (commonly thirty or sixty days) to carry out a member's withdrawal request. $^{93}$ Thus, building and loans were not exposed to the extent

\footnotetext{
${ }^{88}$ Mason (2004), p. 46.

${ }^{89}$ Mason (2004), pp. 40, 47.

${ }^{90}$ Mason (2012), p. 388 (table 2).

${ }^{91}$ Snowden (2010), p. 9.

${ }^{92}$ National Bureau of Economic Affairs, "U.S. Business Cycle Expansions and Contractions." n.d.

${ }^{93}$ Mason (2004), p. 53; Mason (2012), p. 390; Rose (2014), p. 250. The withdrawal process is accurately represented in the 1946 film It's a Wonderful Life, which involved the fictional Bailey Bros. Building and Loan.

TOM: I got two hundred and forty-two dollars in here, and two hundred and fortytwo dollars isn't going to break anybody.

GEORGE (handing him a slip): Okay, Tom. All right. Here you are. You sign this. You'll get your money in sixty days.

TOM: Sixty days?

GEORGE: Well, now that's what you agreed to when you bought your shares.
} 
that banks were to a risky mismatch between long-term assets and short-term liabilities. ${ }^{94}$

Following the crash of 1929 and the ensuing Great Depression, a large number of building and loans did close; the number of associations dropped from 12,342 in 1929 to 8,006 a decade later. ${ }^{95}$ These closures did not result from depositor runs but from the effects of the Depression on the banking sector: as many building and loans required short-term lending from banks (given that their assets were mainly longer-term mortgages), the widespread extent of bank failures led to a short-term credit crunch for the associations. In addition, in the early years of the Depression, building and loan failures were concentrated in Pennsylvania, where building and loans members taking out second mortgages under the Philadelphia plan were unable to roll over their short-term first mortgages (made by a bank or another conventional lender) as the mechanism of the Philadelphia plan assumed. ${ }^{96}$ It is reasonable to assume, also, that the sharp drop in nominal real estate prices $^{97}$ contributed to building and loan closures. During the roughly one hundred years in which local building and loans thrived, however, they played a significant role in extending homeownership through affordable mortgage lending.

\section{INSURANCE COMPANIES AS MORTGAGE LENDERS}

Beyond the business of creating MBS from mortgages and guaranteeing these MBS, insurance companies were important providers of mortgage loans themselves, making mortgages and holding them as investments. Insurance companies accounted for about 7 percent of all mortgages outstanding as of the early 1890 s, meaning about $\$ 400$ million of $\$ 6$ billion outstanding mortgages at that time. ${ }^{98}$ And while, as noted earlier, regulatory prohibitions had limited the ability of some of the largest insurance companies (those located in the state of New York) until the mid-1880s, by the 1920s the major insurance companies were

\footnotetext{
${ }^{94}$ An 1869 tract exhorting working-class Americans to participate in building and loans cited freedom from the risk of runs as an advantage of the associations over depository institutions. Wrigley (1869), pp. 4-5, 47.

${ }^{95}$ Mason (2012), p. 390; Bodfish (1931), p. 136.

${ }^{96}$ Mason (2012), pp. 390-91.

${ }^{97}$ An index of single-family house prices for twenty-two U.S. cities indicates an average drop of 30.4 percent from the pre-Depression peak in 1925 to 1933 . Grebler, Blank, and Winnick (1956), p. 347. An index for Manhattan that includes multifamily dwellings finds a more pronounced 67 percent drop from the third quarter of 1929 to late 1932. Nicholas and Scherbina (2013).

${ }^{98}$ Snowden (1995a), p. 220.
} 
important nationwide mortgage lenders. ${ }^{99}$ Indeed, by 1929 insurance companies had grown in importance as mortgage lenders, so that they were holding 16 percent of the $\$ 47$ billion in all types of mortgage debt then outstanding and were responsible for about 15 percent of all residential mortgages outstanding in $1930 .^{100}$

Because life insurance company liabilities - death benefit payments on life policies and payments on annuity contracts - tend to be longterm and predictable, it is natural that life companies would also tend to hold long-term assets. ${ }^{101}$ Banks, with a high percentage of their funding coming from short-term deposits, wish to limit their exposure to long-term assets for fear that depositors would suddenly demand repayment of deposits, causing a run on the bank. Additionally, given the mismatch in their short-term liabilities and long-term assets, banks face interest rate risk. ${ }^{102}$ Life insurance companies face less of both of these risks, so they tend to have an advantage over banks in holding extremely long-term assets such as mortgages, and they will, as a result, find investments in mortgages to be attractive. ${ }^{103}$

${ }^{99}$ Saulnier (1950), p. 39. Snowden (1995a), pp. 230-42 provides a thorough and fascinating discussion of the means by which life insurance companies handled the delegate-monitoring problem that they faced when lending to mortgagors distant from insurance company headquarters. Much of his discussion focuses on life insurance farm mortgage lending, but it covers residential lending as well.

${ }^{100}$ Saulnier (1950), p. 2. Saulnier (1950), p. 4, notes that as of 1938, the earliest year for which he provides a breakdown by type of mortgage borrower, insurance companies were more important lenders in the commercial mortgage market than in the home-mortgage market. In the home-mortgage market (1-4 family), they held about 8 percent of all outstanding home mortgages ( $\$ 17.1$ billion), while in commercial mortgages they held 39 percent of the total amount outstanding. Snowden (1995a), p. 242, reports that insurance companies held $\$ 4.4$ billion in residential mortgages in 1930 . Grebler, Blank, and Winnick (1956), p. 447, report that total nonfarm residential mortgage debt outstanding in 1930 was $\$ 30.2$ billion. The percentage may be slightly overstated by the extent to which Snowden's figure includes home (residential) mortgages located on farms.

${ }^{101}$ As of June 30, 2017, reserves for future life insurance payments and annuity reserves accounted for 73 percent of all life insurance company liabilities (Board of Governors 2017). We could find no data for insurance company liabilities from the nineteenth century. Saulnier (1950) provides some nineteenth-century data on insurance company assets.

${ }^{102}$ For banks, interest rate risk poses a danger that a shift in market interest rates will reduce their earnings or even produce insolvency. Banks' heavy reliance on shortterm deposits means that their funding tends to reprice quickly in response to shifts in market interest rates; if banks do not quickly respond to market rate movements, their depositors will withdraw their funds and move them elsewhere. As a result, banks must limit the maturities of their assets so that interest rates on these will also move with market rates. If banks fail to do so and market rates increase, the interest rates they earn on their assets will increase less than their interest cost for deposits, and they will suffer losses.

${ }^{103}$ Paulson et al. (2012) discuss and measure the liquidity of life insurance company liabilities and conclude, on page 2, that, "Overall, life insurers have less liquid liabilities than banks do. ...While life insurers have some demand deposit-like products, many of their products have limitations on withdrawals." Still, some modern large life insurers offer a wide range of financial products, a portion of which are quite liquid. For example, 
Single-family home mortgages were an important part of life insurance company mortgage lending but were not the only mortgage lending that they did. According to a survey of twenty-four of the largest life insurance companies, responsible for 65 percent of urban mortgage loans of life insurance companies (covering the years 1920 through 1946), as of the early 1920s, single-family home loans accounted for 78 percent of all urban mortgages made by life companies in numbers of loans and 31 percent in terms of dollars. Mortgages on apartments, stores, "other income properties," 2-4 family homes, and "1-4 family dwellings with a business use" accounted for the remainder of life insurance company mortgages. ${ }^{104}$

Contrary to the typical bank loan of the period, which was nonamortizing and was paid off in full at maturity, in the early 1920s 83 percent of the mortgages made by sampled life insurance companies were fully ( 24 percent) or partially (59 percent) amortizing. Also, they tended to be longer-term than their bank equivalents, with 60 percent having five- to nine-year contract maturities and 27 percent with ten- to fourteen-year maturities. Insurance companies likely were more willing to extend longer-term mortgages than banks because of the long-term nature of insurance company liabilities. ${ }^{105}$

Following the creation of the Federal Housing Administration mortgage loan guarantee program in 1934, during the Great Depression, life insurance companies moved heavily into making FHA-insured and later VA-insured mortgages. ${ }^{106}$ At the same time, these companies began offering fifteen- to twenty-year maturities and twenty-plus-year mortgages. ${ }^{107}$

\section{HOW THESE INSTITUTIONS IMPROVED MORTGAGE TERMS}

\section{Diversification}

As of the 1890s, in terms of dollars, 70 percent of all U.S. mortgage loans were made by individual investors. ${ }^{108}$ Therefore, financial institutions, such as commercial banks, mortgage companies, savings and loans, building and loans, and insurance companies accounted for only

Paulson et al. note that, as of 2011, 11.1 percent of life insurance company liabilities have "high liquidity," liabilities with few limits on early withdrawal, according to their estimates (Table 3, p. 3).

${ }^{104}$ Saulnier (1950), p. 42

${ }^{105}$ Saulnier (1950), pp. 44-45.

${ }^{106}$ U.S. Department of Housing and Urban Development (2017)

${ }^{107}$ Saulnier (1950), p. 45.

108 Snowden (1995a), p. 220. 
30 percent of mortgage holdings. Such a market seems to have been ripe for financial innovations that could allow greater diversification in lending (assuming that individual mortgage investors are unlikely to be well-diversified), access to a wider pool of funds, and therefore offer more affordable mortgages.

One can think in terms of two types of diversification: first, intraregional diversification (the type of diversification allowed by a local lending institution, such as building and loan associations); and second, interregional diversification (the type of diversification allowed by late nineteenth-century MBS, representing mortgages made to borrowers in the western portion of the United States but sold to investors in the East and internationally). By reducing the risk borne by lenders, both types of diversification can reduce mortgage interest rates paid by borrowers.

Many of the individual mortgage investors of the late 1800s were "professional operators or real estate attorneys," or one-time lenders, such as individual home sellers providing purchase money for the buyer of their home, family members, or occasional investors. ${ }^{109}$ Individual home sellers and occasional investors, unless extremely wealthy, and therefore able to make numerous mortgage loans, were likely to have an undiversified mortgage portfolio so that the default of one borrower would cause large proportional losses to their portfolio of mortgage investments. In consequence, such lenders will tend to charge high interest rates to compensate themselves for the substantial credit risk they face.

A lending institution, such as a local bank (or a building and loan association) could gather funds from a large pool of local savers, invest in numerous loans, and diversify away some of the credit risk. This intraregional diversification advantage was likely the genesis for the development of many local lending institutions.

According to estimates made at the time, as of the early 1890s, only 24 percent of individual investor funds came from out of state (meaning interregionally); the remainder came from investors in the same state as the borrower, implying that the providers of most mortgage funding in the United States - individuals - were subject to huge losses from local shocks that lenders with a more geographically diversified pool could avoid. ${ }^{110}$ In 1890, 42 percent of the population lived on farms so that many of these individual investors were likely making mortgage loans to farmers, and likely, due to the size of individual investors'

\footnotetext{
${ }^{109}$ Grebler, Blank, and Winnick (1956), chapter 13, pp. 190-91.

${ }^{110}$ Frederiksen (1894), p. 209.
} 
portfolios, loans concentrated in one or a few localities. ${ }^{111}$ Therefore, these investors' incomes would be subject to large proportional losses if the region were struck with adverse weather - such as an unexpected freeze affecting citrus growers in Florida. Even in nonfarming areas, such as industrial areas, the failure of an important manufacturer would likely lead to trouble for many mortgage borrowers who were employed at a local factory, so that an individual investor's income would be heavily influenced by such shocks. In contrast, a regionally or nationally diversified lender would be better protected.

Similarly, if individual mortgage lenders, meaning individuals with large savings, tended to focus on lending near their home, and such savers were not evenly distributed around the nation, then interest rates could vary considerably from region to region. Regions in which savers were concentrated would have low interest rates and better termssuch as longer-term loans and lower down payments - as these concentrated savers competed among one another to lend to the available borrowers. This seems to have been the case in the northeast portion of the United States in the late nineteenth century, for example. ${ }^{112}$ Further, intermediaries, agents who bought and sold home mortgage loans, apparently, tended to purchase local loans and sell them to local investors. ${ }^{113}$ In contrast, interest rates would be higher in regions with few savers, which implies that more homes would be built (as well as farms established and mortgaged-buildings built) in areas in highsavings regions, say the Northeast, even though there might be greater demand for homes in other areas of the country. ${ }^{114}$ As a result, even though there might be many more new households forming in other regions of the country, and ideally more homes built in other regions, instead households that were completely creditworthy would be unable to afford homes because of high interest rates in those areas where pools of savings were smaller.

The question of whether rates were too high in western and southern states compared to northeastern states has been investigated. Here, too high means borrowers who were equivalently creditworthy received

${ }^{111}$ U.S. Census Bureau (1975), pp. K1-16.

112 See Frederiksen (1894), p. 206; Davis (1965), p. 375. Davis (1965), p. 370, notes that before 1890, national banks in the West sold CDs to investors in the East, but that this activity was criticized by Office of the Comptroller of the Currency examiners.

${ }^{113}$ Frederiksen (1894), p. 221.

${ }^{114}$ Frederiksen (1894), p. 209, notes the inefficiency created by the inability of mortgage funding to flow to its most valuable uses. "So that in America the making of a mortgage loan is essentially a local transaction. ... Under an ideal system of mortgage banking, the capital available for permanent investment would be distributed where most needed. ... In one part of the country the rate of interest paid on a mortgage loan is with equal security twice as high as another." 
higher interest rate loans in southern and western states compared to northeastern borrowers. Davis (1965) argues that while a national market for mortgages had developed throughout most of the country by 1900 , in the South especially and to some extent in the West, mortgage rates remained unusually high as late as $1900 .{ }^{115}$ Eichengreen (1984) analyses the riskiness of farm mortgages and concludes that rate differentials between the East, on the one hand, and the West and South, on the other, can mostly be explained by foreclosure risk differences. Snowden (1987) disagrees with Eichengreen. Snowden analyzes interest rates paid on both farm and home mortgages in 1890 and found that differences could not be explained by default (foreclosure) risk differences and instead that there were remaining regional differences even after accounting for risk.

One reason that investors with available savings tended to lend locally, and especially so when long-range communication and travel was difficult and slow, as in the late 1800s, was that monitoring borrowers was - and still is - costly. Such monitoring could include multiple activities, such as gathering knowledge of local business conditions in order to forecast future land values and ensuring that the borrower maintained the mortgaged property's condition - thereby protecting the lender's collateral interest. But monitoring was less costly for local lenders, given that they could more easily check on the borrower and the collateral (home or farm) and perhaps knew the borrower personally. ${ }^{116}$ When lending at a distance, monitoring collateral preservation meant slowly, and perhaps dangerously, traveling to distant areas to check on collateral or alternatively hiring others (so-called delegated monitoring) to perform this monitoring and then ensuring that these monitors were diligent. Costly investment mistakes arose for distant lenders when delegated monitors were careless or dishonest during the nineteenth century just as they did during the twenty-first century subprime crisis. ${ }^{117}$

Similarly, if the borrower were in default, the lender would be especially eager to keep an eye on the collateral - as in this situation the borrower may be less able (because of a lack of funds) or interested in preserving the property (because she knows that it is unlikely she will be living at the property for very long). The ability to inexpensively visit and check on a property on a very frequent basis would be especially valuable in such situations.

\footnotetext{
${ }^{115}$ Davis (1965), pp. 388-93.

${ }^{116}$ Snowden (1995a), p. 221.

117 Snowden (1995a), pp. 221-30, discusses nineteenth-century arrangements by which distant lenders established and contracted with delegated monitors.
} 
While monitoring costs tended to concentrate mortgage lending in regions with high savings, laws also restricted nationwide lending, which produced efficiency losses for this reason, as discussed earlier. And such laws were, in some cases, quite stringent. For example, in New York, building and loan associations were prohibited from making mortgage loans on properties that were more than fifty miles from the association's headquarters. ${ }^{118}$ Similarly, New York law prohibited insurance companies - the third-largest provider of intermediated mortgages in the early 1890s - from lending outside of the state of New York until 1886, and New York-headquartered insurance companies held a significant share of insurance assets. ${ }^{119}$ A number of other states also prohibited interstate mortgage lending by insurance companies headquartered in their states, though some large insurance companies in Connecticut and Wisconsin enjoyed interstate lending powers. ${ }^{120}$ New York insurance companies saw the earnings that they were missing due to these restrictions and had lobbied aggressively in the 1870s and 1880s to have the restrictions removed. ${ }^{121}$ New York-headquartered insurance companies were aware that interest rates were unusually high in the West and South and had observed insurance companies headquartered in Connecticut successfully provide distant mortgages. Still, even when legislated restrictions were removed, the costs of lending in distant markets were often found to be prohibitive. ${ }^{122}$

\section{Liability Structure}

While lending to borrowers who are unknown to the lender-as are distant borrowers - was costly for insurance companies and other types of mortgage lenders, insurers as well as MBS-issuing companies and building and loan associations likely had an advantage in mortgage lending not available to banks and other deposit-taking institutions. Banks and similar institutions typically fund their loans to a significant degree with short-term deposits. Some of these deposits can even be withdrawn on demand (known as demand deposits). Interest rates on short-term deposits must track market interest rates when rates increase or the bank's customers are likely to withdraw their deposits - when they mature, or immediately in the case of demand deposits - and take them somewhere that offers higher interest rates.

\footnotetext{
118 Herrick and Ingalls (1915), p. 21.

119 See Snowden (1995a), pp. 220, 235.

120 Snowden (1995a), p. 230.

121 Snowden (1995a), p. 235.

122 Snowden (1995a), pp. 218-19 and 235.
} 
The short-term nature of the liabilities of depositories (banks and others) means that these institutions face two risks: (1) the danger of runs - when depositors become frightened of the health of the bank or of the broader economy and suddenly, in force, show up at the bank and want to withdraw their deposits; and (2) interest rate risk.

To address these risks, depositories must take costly measures. To counter the risk of runs, depositories hold large amounts of low interest rate liquid assets (or noninterest earning assets, in the case of cash in the depository's vault), which can be sold quickly, without loss of value, to meet depositor demands during a run. As a result, preparing for runs limits depository institution interest earnings to a degree. To address interest rate risk, depositories tend to limit the maturity of their assets, sacrificing some expected return, to be closer to the maturity of the liabilities. The prohibition on national bank mortgage lending may have been, in part, an effort to control interest rate risk, given that mortgage loans tend to be fairly long term (maturities of at least several years).

Building and loan associations, MBS issuers, and insurance companies were in a better position to offer long-term mortgages than depositories. Building and loans and MBS issuers did not have to hold large amounts of low-earning liquid assets in order to meet runs, given that customers did not have the ability to withdraw on demand; building and loans were largely funded with shares that were quite long-term, and the bonds that funded MBS issuers had long maturities. Similarly, building and loans and MBS issuers faced little interest rate risk given that both their assets (mortgages) and their liabilities (shares and bonds) had similar long-term maturities. While members of many building and loan associations could redeem their shares with thirty days' or sixty days' notice, that notice period made those redemptions quite different in their effect from on-demand withdrawals, given that the associations could obtain the cash to meet a withdrawal in an almost leisurely manner. And the liabilities of insurance companies (and especially of life insurance companies) are fairly predictable streams of payments on insurance policies and annuity contracts, so they are not subject to runs and can easily be matched against long-term assets like mortgages. 
Therefore, building and loans, MBS issuers, and insurance companies did not face the risks that depositories faced from issuing long-term assets. As a result, these nondepository financial institutions were likely to be able to make mortgages at lower interest rates than were depositories. On the other hand, once federal deposit insurance for banks and for savings and loans was created in 1933 and 1934, respectively, the risk of runs was greatly reduced, taking away some of the advantage enjoyed by nondepositories - which may help to explain the historical decline of these nondepository institutions as sources of mortgage loans relative to depositories.

\section{CONCLUSION}

The history set out here highlights a variety of mechanisms through which private institutions have participated in providing affordable mortgage lending: resale or securitization of mortgages (mortgage companies and MBS), mutual self-help (building and loan associations), and portfolio lending (insurance companies). Among the economic efficiencies through which they were able to improve mortgage terms were local-level diversification of mortgage portfolios, interregional diversification of portfolios, and better matching of their liabilities with their long-term assets.

The success of these institutions, over periods of some decades, raises a question of whether they may be relevant to contemporary policy debates. Today, as policymakers consider the prospect of winding down the GSEs, there is concern about the extent to which home mortgage products that are perceived as desirable - particularly long-term, fixed-rate mortgages - would continue to be available in the absence of the GSEs and their implied federal guarantees. In addition, there is concern that without the facilitative role of GSEs in maintaining MBS markets, there may be a major reduction in the extent to which home-mortgage markets have access to funding from capital markets. These, of course, are complex issues that cannot be resolved on the basis of the historical record alone. The history of U.S. mortgage finance does, however, illustrate some of the ways in which private efforts may arise to address demand for affordable mortgages in the absence of public guarantees or subsidies. 


\section{REFERENCES}

Alger, George W., and Alfred A. Cook. 1934. "Report to His Excellency Herbert H. Lehman, Governor of the State of New York." Albany: New York state government document.

Behrens, Carl F. 1952. Commercial Bank Activities in Urban Mortgage Financing. Cambridge, Mass.: National Bureau of Economic Research.

Board of Governors of the Federal Reserve System. 2017. "Financial Accounts of the United States - Z.1. 2017: Q2 Release." Available at:

https://www.federalreserve.gov/releases/z1/current/default.htm [September 21].

Bodfish, Henry Morton, ed. 1931. History of Building and Loan in the United States. Chicago: U.S. Building and Loan League.

Brewer, H. Peers. 1976. "Eastern Money and Western Mortgages in the 1870s." Business History Review 50 (Autumn): 356-80.

Byers, C. Floyd. 1927. "Building and Loan Associations: The Principle Plans of Operation." M.A. thesis, Ohio State University.

Davis, Lance E. 1965. "The Investment Market, 1870-1914: The Evolution of a National Market." Journal of Economic History 25 (September): 355-99.

Dexter, Seymour. 1889. "Co-Operative Savings and Loan Associations." Quarterly Journal of Economics 3 (April): 315-35.

"Downfall of the "Nationals." 1896. Financial Review and American Building Association News 15 (March).

Edson, Charles L. 2011. "Affordable Housing — An Intimate History." In The Legal Guide to Affordable Housing Development, edited by Tim Iglesias and Rochelle E. Lento. Chicago: American Bar Association, 3-20.

Eichengreen, Barry. 1984. "Mortgage Interest Rates in the Populist Era." American Economic Review 74 (December): 995-1015.

Foulke, Roy A. 1941. The Sinews of American Commerce. New York: Dun \& Bradstreet.

Frederiksen, D. M. 1894. "Mortgage Banking in America." Journal of Political Economy 2 (March): 203-34. 
Price \& Walter: Private Efforts for Affordable Mortgage Lending 349

Grebler, Leo, David M. Blank, and Louis Winnick, eds. 1956. Capital Formation in Residential Real Estate. Princeton, N.J.: Princeton University Press.

Griffin, Emma. 2013. Liberty's Dawn: A People's History of the Industrial Revolution. New Haven, Conn.: Yale University Press.

Hansell, Saul. 1995. "Banking's New Giant: The Deal; Chase and Chemical Agree to Merge in $\$ 10$ Billion Deal Creating Largest U.S. Bank." New York Times, August 29.

Haveman, Heather A., and Hayagreeva Rao. 1997. "Structuring a Theory of Moral Sentiments: Institutional and Organizational Coevolution in the Early Thrift Industry." American Journal of Sociology 102 (May): 1606-51.

Herrick, Myron T., and R. Ingalls. 1915. How to Finance the Farmer: Private Enterprise - Not State Aid. Cleveland: The Ohio State Committee on Rural Credits and Cooperation.

JPMorgan. 2017. "About Us, Company History." https://www.jpmorgan.com/country/US/EN/company-history [May 11].

Loucks, William N. 1929. The Philadelphia Plan of Home Financing: A Study of the Second Mortgage Lending of Philadelphia Building and Loan Associations. Chicago: Institute for Research in Land Economics and Public Utilities.

Mason, David L. 2004. From Buildings and Loans to Bail-Outs: A History of the American Savings and Loan Industry, 1831-1995. Cambridge, U.K.: Cambridge University Press.

Mason, David L. 2012. "The Rise and Fall of the Cooperative Spirit: The Evolution of Organizational Structures in American Thrifts, 1831-1939." Business History 54 (June): 381-98.

Nicholas, Tom, and Anna Scherbina. 2013. "Real Estate Prices During the Roaring Twenties and the Great Depression." Real Estate Economics 41 (Summer): 278-309.

Paulson, Anna, Richard Rosen, Zain Mohey-Deen, and Robert McMenamin. 2012. "How Liquid are U.S. Life Insurance Liabilities?" Federal Reserve Bank of Chicago Fed Letter 302 (September).

Price, Seymour J. 1958. Building Societies: Their Origin and History, London: Franey \& Co. 
Rose, Jonathan D. 2014. "The Prolonged Resolution of Troubled Real Estate Lenders During the 1930s." In Housing and Mortgage Markets in Historical Perspective, edited by Eugene N. White, et al. Chicago: University of Chicago Press, 245-84.

Saulnier, R. J., ed. 1950. Urban Mortgage Lending by Life Insurance Companies. Cambridge, Mass.: National Bureau of Economic Research.

Snowden, Kenneth A. 1987. "Mortgage Rates and American Capital Market Development in the Late Nineteenth Century." Journal of Economic History 47 (September): 671-91.

Snowden, Kenneth A. 1995a. "The Evolution of Interregional Mortgage Lending Channels, 1870-1940: The Life Insurance-Mortgage Company Connection." In Coordination and Information: Historical Perspectives on the Organization of Enterprise, edited by Naomi R. Lamoreaux and Daniel M.G. Raff. Chicago: University of Chicago Press, 209-56.

Snowden, Kenneth A. 1995b. "Mortgage Securitization in the United States: Twentieth Century Developments in Historical Perspective." In Anglo-American Financial Systems: Institutions and Markets in the Twentieth Century, edited by Michael D. Bordo and Richard Sylla. New York: Irwin, 261-98.

Snowden, Kenneth A. 1997. "Building and Loan Associations in the U.S., 1880-1893: The Origins of Localization in the Residential Real Estate Market." Research in Economics 51 (September): $227-50$.

Snowden, Kenneth A. 2010. "The Anatomy of a Residential Mortgage Crisis: A Look Back to the 1930s." Working Paper 16244.

Cambridge, Mass.: National Bureau of Economic Research. (July).

Tcherkinsky, M. 1922. The Landschaften and Their Mortgage Credit Operations in Germany, 1770-1920. Rome: Printing Office of the International Institute of Agriculture, Bureau of Economic and Social Intelligence.

U.S. Bureau of the Census. 1975. Historical Statistics of the United States: Colonial Times to 1970. Washington, D.C.: U.S. Department of Commerce.

U.S. Department of Housing and Urban Development. 2017. "The Federal Housing Administration (FHA)." https://portal.hud.gov/hudportal/HUD?src=/program_offices/ housing/fhahistory [May 11]. 
Price \& Walter: Private Efforts for Affordable Mortgage Lending 351

Wandschneider, Kirsten. 2014. "Lending to Lemons: Landschaft Credit in Eighteenth-Century Prussia." In Housing and Mortgage Markets in Historical Perspective, edited by Eugene N. White, et al. Chicago: University of Chicago Press, 305-25.

Wandschneider, Kirsten. 2015. "Landschaften as Credit Purveyors The Example of East Prussia." Journal of Economic History 75 (September): 791-818.

White, Eugene N. 2014. "Lessons from the Great American Real Estate Boom and Bust of the 1920s." In Housing and Mortgage Markets in Historical Perspective, edited by Eugene N. White, et al. Chicago: University of Chicago Press, 115-58.

Wrigley, Edmund. 1869. The Working Man's Way to Wealth; A Practical Treatise on Building Associations: What They Are and How to Use Them. Philadelphia: James K. Simon. 